\title{
Observations on the Epidemiology of Poliomyelitis
}

\author{
By W. THURBER FALES, SC. D., and MATTHEW TABACK, A. M.
}

Some evidence to support the theory that poliomyelitis is spread from person to person is found in a study of the 1950 poliomyelitis epidemic in Baltimore City.

The 212 cases of paralytic poliomyelitis reported to the city health department during 1950 represent the highest annual total of reported cases ever recorded in Baltimore. The attack rate of 22.5 per 100,000 during 1950 was exceeded only once when 206 cases were reported in 1916-a rate of 33.9.

This comparatively high incidence offered material for a study of the probable mode of transmission of this disease and of its selection of specific population elements.

However, until we have reasonably accurate estimates of the incidence of newly acquired infections, conclusions drawn from a study of paralytic cases only are limited and incapable of yielding a clear definition of the epidemiology of poliomyelitis.

\section{History of Poliomyelitis in Baltimore}

Baltimore City has no record of poliomyelitis mortality or morbidity prior to 1912. Cases and case rates for each $\check{5}$-year interval from 1912 to 1950 are given in table 1 . Annual incidence and mortality ascribed to poliomyelitis are shown in the basic table 9. Recognition of this disease and reporting practices presumably are quite different today than they were several decades ago. Since 1934, when non-

Dr. Fales is director of the statistical section and Mr. Taback is director of the bureau of biostatistics, Baltimore City Health Department. paralytic cases were specifically excluded, extreme annual variations in incidence have occurred. The number of cases have varied from 3 to 212 and the case rates, from 0.32 to 22.5 per 100,000 population. No clear-cut time sequence can be developed on an annual basis. When attack rates are considered for white and Negro segments of the population, reported

\begin{tabular}{|c|c|c|c|c|c|c|}
\hline \multirow{2}{*}{ Period } & \multicolumn{3}{|c|}{ Annual average number } & \multicolumn{3}{|c|}{$\begin{array}{l}\text { Number per } 100,000 \text { popu- } \\
\text { lation }\end{array}$} \\
\hline & Total & White & Negro & Total & White & Negro \\
\hline $\begin{array}{l}1950 \\
1945-49 \\
1940-44 \\
1935-39 \\
1930-34 \\
1925-29 \\
1920-24 \\
1915-19 \\
1912-14\end{array}$ & $\begin{array}{r}212 \\
34 \\
57 \\
26 \\
15 \\
41 \\
66 \\
71 \\
9\end{array}$ & $\begin{array}{c}169 \\
29 \\
51 \\
22 \\
13 \\
37 \\
58 \\
\left({ }^{2}\right) \\
(2)\end{array}$ & $\begin{array}{r}43 \\
5 \\
6 \\
4 \\
2 \\
4 \\
8 \\
(2) \\
(2)\end{array}$ & $\begin{array}{r}23.3 \\
3.6 \\
6.2 \\
3.1 \\
1.8 \\
5.2 \\
8.8 \\
11.5 \\
1.5\end{array}$ & \begin{tabular}{r}
22.7 \\
3.9 \\
7.0 \\
3.2 \\
1.9 \\
5.7 \\
9.1 \\
\hdashline--- \\
$-0-$
\end{tabular} & $\begin{array}{r}19.0 \\
2.5 \\
3.3 \\
2.5 \\
1.4 \\
3.0 \\
6.8 \\
\\
\end{array}$ \\
\hline
\end{tabular}

1 Since 1935 only paralytic cases are included in this table.
2 Not available.

morbidity among Negroes is consistently, but not markedly, lower than that recorded for white persons.

The epidemic of 1950 was preceded by a 5year period of comparatively constant incidence. The average annual number of cases was 34 , and the corresponding rate was 3.6 per 100,000. During this period, the case fatality ratio was 8.9 percent. Previous years of high incidence were 1944 and 1941. It is essential to recall also that the extraordinarily high birth rates from 1945 to 1949 added to the population approximately 100,000 young children-10 percent of the entire population. 


\section{Epidemic of 1950}

Distribution of paralytic cases reported for 1950 according to week of onset shows September 3 as the median point for the whole population (table 2 and fig. 1). There is remarkable uniformity in the curves for white and Negro segments. The median points are September 6 and August 29, respectively.

Table 2. Reported cases of paralytic poliomyelitis by week of onset for white and Negro persons, Baltimore City, 1950

\begin{tabular}{|c|c|c|c|}
\hline Month and week & Total & White & Negro \\
\hline Total $\ldots \ldots$ & 212 & 169 & 43 \\
\hline $\begin{array}{r}1 \\
\text { June } \\
15 \\
22 \\
29\end{array}$ & 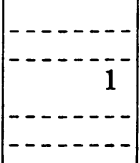 & 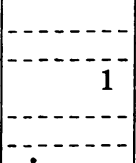 & 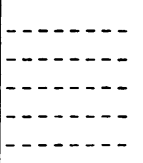 \\
\hline $\begin{array}{r}7 \\
\text { July } 14 \\
21 \\
28\end{array}$ & $\begin{array}{l}2 \\
4 \\
4 \\
7\end{array}$ & $\begin{array}{l}2 \\
4 \\
\mathbf{2} \\
\mathbf{5}\end{array}$ & $\begin{array}{r}2 \\
2\end{array}$ \\
\hline 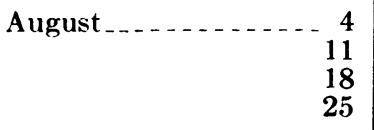 & $\begin{array}{l}13 \\
14 \\
10 \\
14\end{array}$ & $\begin{array}{r}9 \\
10 \\
8 \\
10\end{array}$ & $\begin{array}{l}4 \\
4 \\
2 \\
4\end{array}$ \\
\hline $\begin{array}{r}1 \\
8 \\
15 \\
22 \\
29\end{array}$ & $\begin{array}{l}26 \\
32 \\
16 \\
14 \\
15\end{array}$ & $\begin{array}{l}18 \\
25 \\
12 \\
13 \\
13\end{array}$ & $\begin{array}{l}8 \\
7 \\
4 \\
1 \\
2\end{array}$ \\
\hline $\begin{array}{r}5 \\
12 \\
19 \\
26\end{array}$ & $\begin{array}{r}10 \\
7 \\
8 \\
4\end{array}$ & $\begin{array}{l}9 \\
6 \\
8 \\
3\end{array}$ & \\
\hline $\begin{array}{r}\text { November } \ldots r \\
9 \\
16 \\
23 \\
30\end{array}$ & $\begin{array}{r}\mathbf{5} \\
\mathbf{3} \\
\mathbf{2} \\
--2--\end{array}$ & $\begin{array}{r}5 \\
3 \\
2 \\
\hdashline-1- \\
\hdashline-10\end{array}$ & 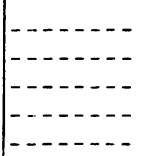 \\
\hline $\begin{array}{r}7 \\
14 \\
21 \\
28\end{array}$ & 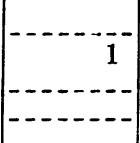 & 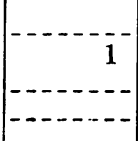 & 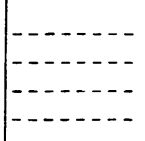 \\
\hline
\end{tabular}

The range of the curve for the total population extends from July 1 to November 16. If consideration is confined to the weeks of excessive incidence, ${ }^{1}$ the epidemic range extends from approximately July 29 to October 19, a period

\footnotetext{
${ }^{1}$ Median weekly frequencies based upon experience during 1945-49 were used to determine the interval during which poliomyelitis was present at above-average levels.
}

of 12 weeks. Thus, the hypothesis of a common source single-exposure epidemic is inconsistent with the distribution of cases by time of onset of disease, since the epidemic course extended beyond 35 days (1) - the extreme estimate of the incubation period for poliomyelitis.

It is the practice of the bureau of biostatistics in Baltimore to spot cases of poliomyelitis on a city census tract map according to the residence of the patient. During the 1950 epidemic, there was a gradual movement from the hub of the city to the periphery in the time sequence in which cases were reported. This movement is shown in a series of spot maps in figure 2 and summarized in table 3 .

Figure 1. Reported cases of paralytic poliomyelitis by week of onset and population segment, Baltimore City, 1950.

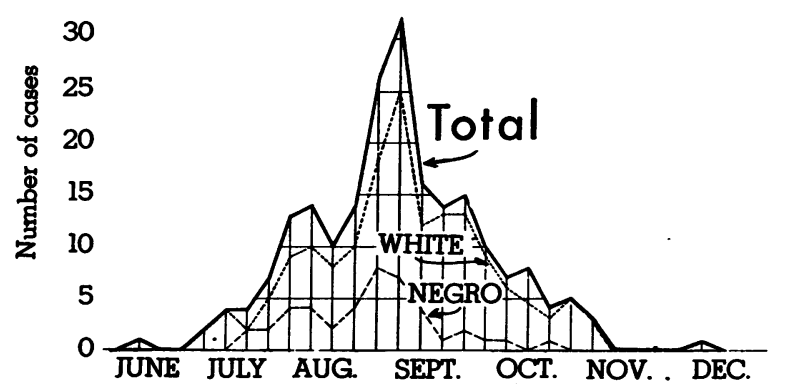

The median date of onset, a convenient index of central tendency, falls on August 25 for the cases in the center of the city. It was 3 weeks later (September 15) before the median case was attacked in the periphery of the city. A test of this difference indicates the improbability that it was caused by chance. The observation of a significant time differential in the case distribution for specified city areas makes it extremely unlikely that the disease process was associated with exposure to a common source.

\section{Mode of Transmission}

Having rejected a common source as a probable mode of transmission, is there any evidence which would be consistent with a hypothesis that poliomyelitis is a propagated epidemic?

An analysis of the spot maps in figure 2 indicates the presence of a sporadic distribution of cases throughout the city during the early phase of the epidemic period. However, one 
Figure 2. Cases of paralytic poliomyelitis according to broad city zones and date of onset, Baltimore City, 1950.
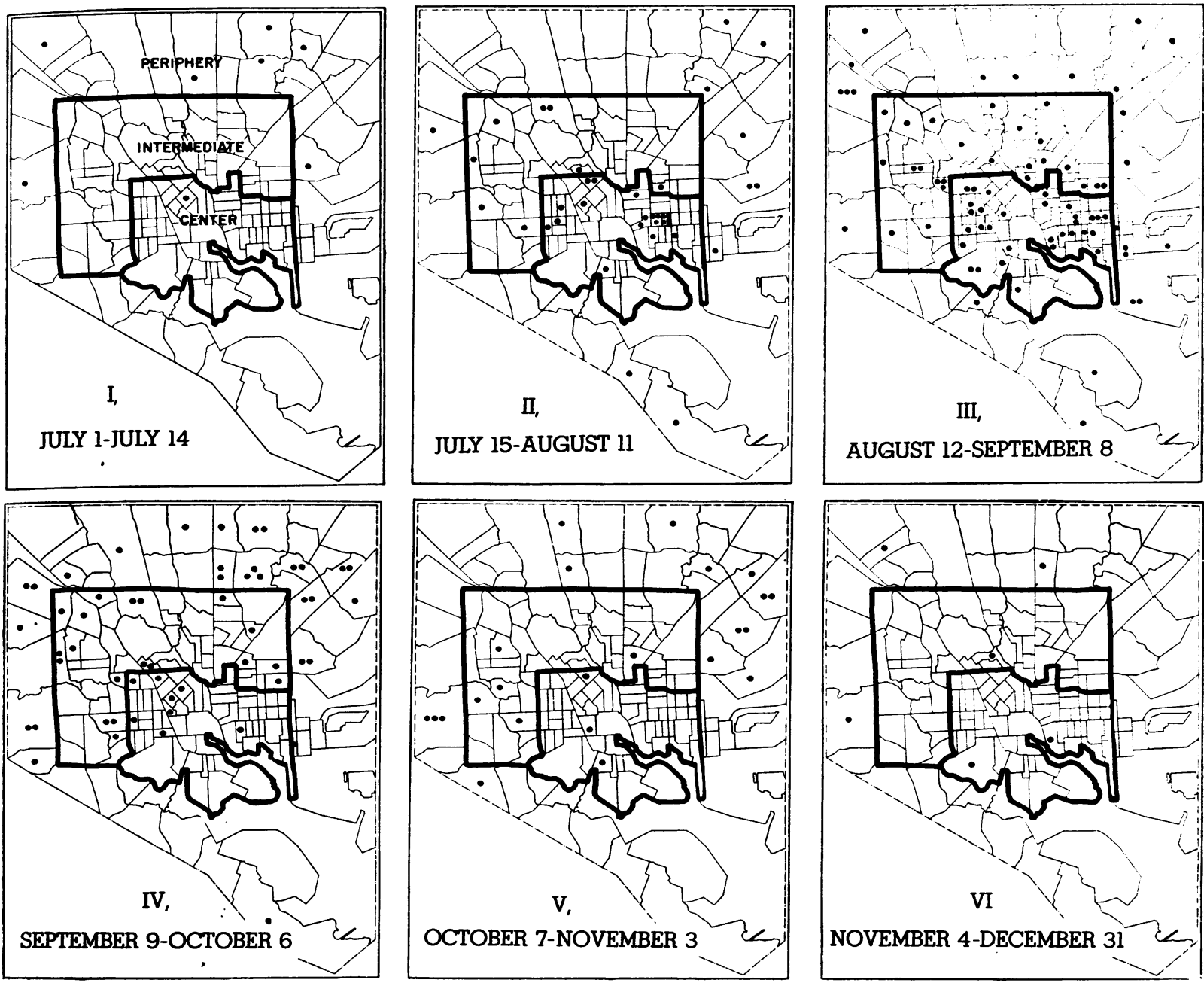

then observes a variable rate of progress in specified zones. The most rapid spread in time occurred in the central area of the city and the slowest development, in the peripheral zone.

The data presented on time differentials in the progress of the epidemic in selected city zones is explainable by the logical thesis that opportunities for interpersonal contact are somewhat less in the peripheral areas as compared with the central zone of the city. It

Table 3. Cases of paralytic poliomyelitis according to geographic zones and month of onset, Baltimore area, 1950

\begin{tabular}{|c|c|c|c|c|c|c|c|c|c|}
\hline Area & Total & $\underset{\text { Jume }}{\text { January- }}$ & July & August & September & October & November & December & $\begin{array}{l}\text { Date of } \\
\text { median } \\
\text { case }\end{array}$ \\
\hline $\begin{array}{l}\text { Intracity zones: } \\
\text { Center } \\
\text { Intermediate. } \\
\text { Periphery } \\
\text { Baltimore County } 1\end{array}$ & $\begin{array}{l}67 \\
60 \\
85 \\
90\end{array}$ & $\begin{array}{c}1 \\
1\end{array}$ & $\begin{array}{r}10 \\
2 \\
7 \\
6\end{array}$ & $\begin{array}{l}28 \\
22 \\
20 \\
14\end{array}$ & $\begin{array}{l}23 \\
27 \\
32 \\
35\end{array}$ & $\begin{array}{r}3 \\
8 \\
22 \\
26\end{array}$ & $\begin{array}{l}2 \\
1 \\
3 \\
8\end{array}$ & $\begin{array}{l}\mathbf{0} \\
\mathbf{0} \\
1 \\
\mathbf{0}\end{array}$ & $\begin{array}{l}\text { Aug. } 25 \\
\text { Sept. } 8 \\
\text { Sept. } 15 \\
\text { Sept. } 22\end{array}$ \\
\hline
\end{tabular}

1 Dr. William Warthen provided the morbidity experience for paralytic poliomyelitis in Baltimore County, an area completely surrounding the peripheral zone of the city. The incidence distribution assumes a time sequence similar to that experienced in the adjacent city zone. 
Table 4. Total cases and annual average attack rates for poliomyelitis, Baltimore City, 1938-42

\begin{tabular}{|c|c|c|c|c|c|}
\hline \multirow{3}{*}{ Economic group } & \multicolumn{5}{|c|}{ Age group (years) } \\
\hline & \multicolumn{5}{|c|}{ Number of cases (5-year total) } \\
\hline & Total & $0-4$ & $5-9$ & $10-14$ & $\begin{array}{l}15 \text { and } \\
\text { over }\end{array}$ \\
\hline \multirow{3}{*}{$\begin{array}{l}\text { Lower }{ }^{1} \ldots \ldots \\
\text { Upper }\end{array}$} & 131 & 43 & 44 & 22 & 22 \\
\hline & $\begin{array}{l}55 \\
76\end{array}$ & $\begin{array}{l}27 \\
16\end{array}$ & $\begin{array}{l}18 \\
26\end{array}$ & $\begin{array}{r}7 \\
15\end{array}$ & $\begin{array}{r}3 \\
19\end{array}$ \\
\hline & \multicolumn{5}{|c|}{ Annual average cases per $1,000,000$} \\
\hline Total $\ldots . .$. & 30. 4 & 153 & 150 & 65 & 6. 6 \\
\hline $\begin{array}{l}\text { Lower } \\
\text { Upper }\end{array}$ & $\begin{array}{l}32.0 \\
29.4\end{array}$ & $\begin{array}{l}207 \\
107\end{array}$ & $\begin{array}{l}134 \\
169\end{array}$ & $\begin{array}{l}45 \\
85\end{array}$ & $\begin{array}{l}2.4 \\
8.6\end{array}$ \\
\hline
\end{tabular}

1 Includes 40 percent of total population.

follows, then, that the disease is a slower moving process during a given period in areas characterized by low contact rates; it exhibits also a retarded attack sequence by age.

An analysis of attack rates by age for 1950 according to areas of the city cannot be

Table 5. Annual average attack rates ${ }^{1}$ by age, Baltimore City

\begin{tabular}{|c|c|c|c|c|c|}
\hline \multirow[b]{2}{*}{ Period } & \multicolumn{5}{|c|}{ Age groups (years) } \\
\hline & Total & $0-4$ & 5-9 & $10-14$ & $\begin{array}{c}15 \text { and } \\
\text { over }\end{array}$ \\
\hline $\begin{array}{l}1928-32 \\
1938-42 \\
1948-50\end{array}$ & $\begin{array}{r}41.6 \\
30.2 \\
105.0\end{array}$ & $\begin{array}{l}232 \\
143 \\
373\end{array}$ & $\begin{array}{l}180 \\
150 \\
413\end{array}$ & $\begin{array}{r}52 \\
65 \\
227\end{array}$ & $\begin{array}{r}3 \\
7 \\
29\end{array}$ \\
\hline
\end{tabular}

1 Per 1,000,000 population.

made at present in the absence of population data. However, when the 5-year experience of $1938-42$ is distributed by age and broad socioeconomic zones, the earlier attack of a densely settled population is evidenced by the fact that peak rates are at the age range

Table 6. Annual average attack rates by age expressed as percentages of rates for $0-4$ years, Baltimore City

\begin{tabular}{r|r|r|r|r}
\hline \multirow{2}{*}{ Period } & \multicolumn{4}{|c}{ Age groups (years) } \\
\cline { 2 - 4 } & \multicolumn{1}{|c|}{$0-4$} & \multicolumn{1}{|c|}{$5-9$} & $10-14$ & 15 and over \\
\hline $1928-32$ & 100 & 78 & 22 & 1.3 \\
$1938-42$ & 100 & 105 & 45 & 4.6 \\
$1948-50$ & 100 & 11 & 61 & 7.8 \\
\hline
\end{tabular}

$0-4$ as compared to a peak of 5-9 in a less densely populated segment (table 4). The correspondence in total attack rates is evidence of an infectious process which eventually reaches an entire population group.

Table 7. Cases, case rates, and percentage distribution of paralytic poliomyelitis by age for white and Negro persons, Baltimore City, 1950

\begin{tabular}{|c|c|c|c|c|c|}
\hline \multirow{2}{*}{ Group } & Total & $0-4$ & $5-9$ & $10-14$ & and over \\
\hline & \multicolumn{5}{|c|}{ Number of cases } \\
\hline \multirow[t]{3}{*}{ Total $\ldots . .}$. & 212 & 85 & 64 & 21 & 42 \\
\hline & $\begin{array}{r}169 \\
43\end{array}$ & $\begin{array}{l}60 \\
25\end{array}$ & $\begin{array}{l}53 \\
11\end{array}$ & $\begin{array}{r}19 \\
2\end{array}$ & $\begin{array}{r}37 \\
5\end{array}$ \\
\hline & \multicolumn{5}{|c|}{ Cases per $1,000,000$ population } \\
\hline Total ..... & 225 & 833 & 967 & 375 & 59 \\
\hline \multirow[t]{2}{*}{$\begin{array}{l}\text { White } \ldots \ldots \\
\text { Negro } \ldots \ldots\end{array}$} & $\begin{array}{l}233 \\
190\end{array}$ & $\begin{array}{l}800 \\
890\end{array}$ & $\begin{array}{r}1,060 \\
680\end{array}$ & $\begin{array}{l}415 \\
135\end{array}$ & $\begin{array}{l}64 \\
35\end{array}$ \\
\hline & \multicolumn{5}{|c|}{ Proportionate distribution } \\
\hline Total $\ldots . .$. & 100 & 40 & 30 & 10 & 20 \\
\hline $\begin{array}{l}\text { White } \\
\text { Negro........ }\end{array}$ & $\begin{array}{l}100 \\
100\end{array}$ & $\begin{array}{l}35 \\
58\end{array}$ & $\begin{array}{l}30 \\
26\end{array}$ & $\begin{array}{r}11 \\
5\end{array}$ & $\begin{array}{l}22 \\
12\end{array}$ \\
\hline
\end{tabular}

Further support for the person-to-person contact basis for transmission of poliomyelitis

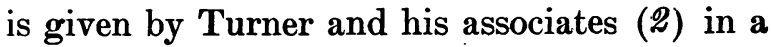
study on the age incidence of infection by Lansing poliomyelitis virus. 'These investigators, working with the Lansing strain of polio-

Table 8. Reported cases of paralytic poliomyelitis by type and age, Baltimore City, 1950

\begin{tabular}{|c|c|c|c|c|c|}
\hline Type & All ages & $0-4$ & $5-9$ & $10-14$ & and over \\
\hline Total $\ldots$ & 212 & 85 & 64 & 21 & 42 \\
\hline $\begin{array}{l}\text { Bulbar } \\
\text { Bulbar spinal } \\
\text { Spinal } \\
\text { Percent bulbar. }\end{array}$ & $\begin{array}{r}35 \\
7 \\
170 \\
17\end{array}$ & $\begin{array}{r}7 \\
2 \\
76 \\
8\end{array}$ & $\begin{array}{r}15 \\
2 \\
47 \\
23\end{array}$ & $\begin{array}{r}5 \\
1 \\
15 \\
24\end{array}$ & $\begin{array}{r}8 \\
2 \\
32 \\
19\end{array}$ \\
\hline
\end{tabular}

myelitis, find that the distribution, according to age of positive Lansing neutralization tests, shows a general similarity to cumulative age distributions for such conditions as measles, mumps, chickenpox, and whooping cough-all 
Table 9. Poliomyelitis cases by month of report and toial deaths, 1912-50, Baltimore City

\begin{tabular}{|c|c|c|c|c|c|c|c|c|c|c|c|c|c|c|}
\hline Year & $\begin{array}{l}\text { Total } \\
\text { deaths }\end{array}$ & $\begin{array}{l}\text { Total } \\
\text { cases }\end{array}$ & January & $\underset{\text { ary }}{\text { Febru- }}$ & March & April & May & June & July & August & $\begin{array}{c}\text { Septem- } \\
\text { ber }\end{array}$ & October & $\begin{array}{c}\text { Novem- } \\
\text { ber }\end{array}$ & $\begin{array}{c}\text { Decem. } \\
\text { ber }\end{array}$ \\
\hline 1912. & 6 & 25 & & & & & & & & 13 & 8 & 4 & & \\
\hline 191: & 1 & 2 & & & 1 & & & & 1 & & & & 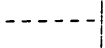 & \\
\hline $\begin{array}{l}1914 \\
1915\end{array}$ & $\begin{array}{l}1 \\
5\end{array}$ & 26 & & & & & & 1 & 11 & $\begin{array}{r}1 \\
13\end{array}$ & 1 & & & \\
\hline 1916 & 70 & 206 & $\ldots$ & -- & 2 & & & $=-$ & 3 & 37 & 71 & 74 & 17 & $\overline{2}$ \\
\hline $188_{-}$ & 5 & 38 & & & 1 & & & 8 & $\begin{array}{r}2 \\
11\end{array}$ & & 8 & 3 & & \\
\hline 1919 & 28 & 83 & & & & & 1 & 2 & 9 & 27 & 20 & 16 & 7 & 1 \\
\hline 1920 _ & 4 & 15 & 3 & 1 & & & & 3 & 1 & 2 & 3 & 1 & 1 & \\
\hline & 22 & 148 & 1 & 1 & & & & 3 & 12 & 37 & 40 & 41 & 11 & 2 \\
\hline 1922 & $\begin{array}{l}3 \\
1\end{array}$ & $\begin{array}{l}26 \\
11\end{array}$ & $\begin{array}{l}1 \\
2\end{array}$ & $\begin{array}{l}3 \\
2\end{array}$ & & & & 2 & $\begin{array}{l}3 \\
1\end{array}$ & 2 & $\begin{array}{l}5 \\
2\end{array}$ & 4 & $\begin{array}{l}5 \\
1\end{array}$ & 1 \\
\hline 1924 & 10 & 131 & 1 & 1 & $-\ldots$ & 1 & 1 & 2 & 13 & 44 & 37 & 25 & 4 & 2 \\
\hline 25 & 9 & $\begin{array}{l}28 \\
28\end{array}$ & 1 & 1 & -- & 2 & 1 & 4 & 5 & 3 & 8 & 3 & & $i$ \\
\hline $\begin{array}{l}1926-- \\
1927 .-\end{array}$ & $\begin{array}{l}7 \\
3\end{array}$ & $\begin{array}{l}28 \\
11\end{array}$ & . & & & & & & 6 & $\begin{array}{l}8 \\
1\end{array}$ & 8 & $\begin{array}{l}4 \\
5\end{array}$ & $\begin{array}{l}1 \\
2\end{array}$ & $\begin{array}{l}1 \\
3\end{array}$ \\
\hline $28 \ldots$ & 8. & $12 \overline{7}$ & & & & & 3 & 5 & 12 & 66 & 28 & 8 & 3 & 2 \\
\hline 1929 & & 9 & 1 & 1 & & & & & 1 & 1 & 1 & 2 & 2 & \\
\hline 1930 & 3 & 21 & & & 1 & & 1 & $\ldots$ & 2 & 2 & 2 & 8 & 4 & 1 \\
\hline & 3 & 14 & & 1 & & & & & $\cdots$ & 3 & 4 & 3 & $\begin{array}{l}3 \\
2\end{array}$ & $\cdots$ \\
\hline $\begin{array}{l}1932 \\
1933\end{array}$ & $\begin{array}{l}2 \\
2\end{array}$ & $\begin{array}{l}13 \\
17\end{array}$ & 1 & & & & 1 & & 5 & $\begin{array}{l}1 \\
3\end{array}$ & $\begin{array}{l}5 \\
2\end{array}$ & $\begin{array}{l}3 \\
4\end{array}$ & 1 & $\overline{2}$ \\
\hline 1934 & 1 & 9 & & & 1 & & & & & 3 & 3 & $\ldots$ & 1 & 1 \\
\hline & 3 & 54 & & 1 & 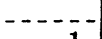 & 1 & & & 4 & 11 & 23 & 9 & 5 & $i$ \\
\hline $\begin{array}{l}1950- \\
1937 .\end{array}$ & 9 & $\begin{array}{r}7 \\
47\end{array}$ & & & 1 & & & & $\begin{array}{l}1 \\
7\end{array}$ & 17 & $\begin{array}{r}4 \\
17\end{array}$ & 4 & 1 & $\begin{array}{l}1 \\
1\end{array}$ \\
\hline 1938 & & 3 & 1 & & & & & 1 & & & 1 & & & \\
\hline - 1939 & & 20 & & & & & & & & 2 & 5 & 9 & 3 & 1 \\
\hline 94 & & 4 & & & & 1 & & & & 2 & & & 1 & - \\
\hline & 3 & $\begin{array}{r}101 \\
3\end{array}$ & 1 & 3 & & 1 & & 1 & 18 & 50 & 19 & 6 & 2 & \\
\hline & & 8 & & & & & & & 1 & 1 & 2 & 2 & 2 & $\ldots$ \\
\hline 1944 & 12 & 167 & & & & & & 1 & 12 & 58 & 64 & 25 & 6 & 1 \\
\hline & & 21 & & & & & & 1 & 2 & 7 & 5 & 5 & 1 & 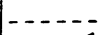 \\
\hline & 4 & 34 & & 1 & & & & & 2 & & & 11 & 8 & 1 \\
\hline 1947 & $\begin{array}{l}4 \\
2\end{array}$ & 29 & 1 & 1 & 1 & $\cdots$ & 1 & & 1 & 7 & 10 & 5 & 1 & 1 \\
\hline $1949 \ldots$ & $\begin{array}{l}2 \\
5\end{array}$ & $\begin{array}{l}24 \\
61\end{array}$ & 1 & $\ldots$ & 1 & . & $-\ldots$ & 1 & $\begin{array}{l}3 \\
3\end{array}$ & $\begin{array}{r}4 \\
11\end{array}$ & $\begin{array}{r}8 \\
13\end{array}$ & $\begin{array}{r}7 \\
17\end{array}$ & $\begin{array}{r}2 \\
11\end{array}$ & 3 \\
\hline $1950 \ldots$ & 8 & 212 & & & & & & 1 & 19 & 71 & 81 & 33 & 6 & 1 \\
\hline
\end{tabular}

' Beginning with 1935 nonparalytic cases have been specifically excluded.

diseases whose transmission appears to be based on a person-to-person contact principle. As indicated later several other characteristics of poliomyelitis appear to be consistent with this mode of transmission.

\section{Age Selection in Successive Decades}

In table 5, attack rates by broad age groups are shown for three periods centered about a year of the decennial census. As an aid in sensing age selection, table 6 presents the age specific rates for each age period as percentages of the rate for $0-4$ years.
During three decades, the tendency has been toward a greater selection of older age groups for attack. This, we feel, is entirely consistent with a thesis of person-to-person contact. Proportionately, during the past 30 years the percentage of population residing in densely populated areas has declined and family units have become smaller. There has also been a tendency toward reduction of the probability of interpersonal contact, particularly at school and preschool ages. This in turn has led to a retardation in the exposure of new susceptibles to poliomyelitis infection. 


\section{Negro Rates Lower}

During the 10-year interval 1940 to 1949 , the annual attack rate among Negroes has averaged 2.7 per 100,000 as compared with the white attack rate of 5.4.

Turner and associates (2) indicate an earlier exposure in Negroes than in white residents to Lansing poliomyelitis, and this is substantiated by recorded attack rates for 1950 (table 7). Since early exposure appears to result in a milder form of disease (table 8) there is reason to believe that the lower Negro morbidity rates for poliomyelitis are a reflection of earlier exposure, not of less exposure, which is entirely consistent with a person-to-person concept of transmission.

\section{Seasonal Character}

With very few exceptions from 1912 to 1950 , poliomyelitis has originated in early summer, reached a peak in September, and terminated in November or December (table 9). The seasonal distribution of poliomyelitis is one of the attributes of the disease which is difficult to explain solely on the person-to-person mode of transmission. This characteristic is one of the principal elements in the epidemiology of poliomyelitis which awaits clarification. There exists perhaps a virulence or growth factor in the poliomyelitis agent which is seasonal in variation, but this remains to be demonstrated experimentally. Variation in host factors is another possible explanation awaiting further investigation.

\section{Summary}

1. Consideration of the distribution of cases according to white and Negro persons and geographic areas during the 1950 poliomyelitis epidemic in Baltimore City has led to a rejection of the hypothesis that the epidemic could have been caused by a common source vehicle.

2. Evidence for regarding poliomyelitis as a propagated disease of the person-to-person type has been presented.

3. Selection for attack of older groups in higher socioeconomic levels has been demonstrated to be consistent with the hypothesis of regarding poliomyelitis as a disease propagated by interpersonal contact.

\section{ACKNOWLEDGMENT}

Acknowledgment is made of the assistance of Dr. J. W. Davis and Dr. M. G. Tull of the Baltimore City Health Department.

\section{REFERENCES}

(1) The control of communicable diseases in man. New York, The American Public Health Association, 1950.

(2) Turner, T. B., Hollander, D. H., Buckley, S., Kokke, U. P., and Winsor, C. P.: Age incidence and seasonal development of neutralizing antibodies to Lansing poliomyelitis virus. Am. J. Hyg. 52 : 323-347 (1950). 